\title{
Development of Pemphigus Vulgaris-like Lesions in Severe Combined Immunodeficiency Disease Mice Reconstituted with Lymphocytes from Patients
}

\author{
Istvan Juhasz, * Gerald S. Lazarus, ${ }^{\star}$ George F. Murphy, ${ }^{\star}$ le-Ming Shih, ${ }^{\star}$ and Meenhard Herlyn * \\ ${ }^{*}$ The Wistar Institute of Anatomy and Biology, and the ${ }^{\ddagger}$ Department of Dermatology, \\ University of Pennsylvania School of Medicine, Philadelphia, Pennsylvania 19104
}

\begin{abstract}
Pemphigus vulgaris is an autoimmune blistering disease that is induced by binding of antibodies to a $130 / 85-\mathrm{kD}$ protein complex on epidermal keratinocytes. An in vivo experimental model of this disease was developed by reconstituting severe combined immunodeficiency (SCID) mice with 1-10 $\times 10^{7}$ PBL from patients with naturally occurring pemphigus vulgaris. Of 49 reconstituted mice, 34 (69\%) produced human IgG levels of $>0.1 \mathrm{mg} / \mathrm{ml}$. Circulating anti-pemphigus antibodies were found in 20 of the 34 successfully reconstituted mice; $44 \%$ of these animals had deposits of human IgG in their own skin after it was traumatized by either heat or cold. Spontaneous pemphigus vulgaris-like blisters associated with human IgG deposits were rarely found in mouse skin. By contrast, allogeneic human skin grafted to $\mathbf{1 0}$ of 12 mice before reconstitution with patients' PBL developed pemphigus vulgaris-like lesions containing human IgG deposits. These results demonstrate that SCID mice can serve as a model of an antibody-mediated human autoimmune skin disease. (J. Clin. Invest. 1993. 92:24012407.) Key words: skin autoimmune disease • animal model • antibodies $\cdot$ pemphigus
\end{abstract}

\section{Introduction}

Pemphigus vulgaris (PV) ${ }^{1}$ is an autoimmune disease of skin and mucous membranes. Because of severe and extensive blistering, the disease can be fatal if untreated. It is mediated by antibodies to an epithelial-specific, intercellular antigen found in the suprabasal epidermis and mucosal epithelial layer. The PV antigen is a $130-\mathrm{kD}$ glycoprotein (1) which is disulfidelinked to the $85-\mathrm{kD}$ placoglobin (2). cDNA cloning has recently identified the PV antigen as a member of the cadherin family of $\mathrm{Ca}^{2+}$-dependent cell adhesion molecules (3). Blister formation after antibody binding to the PV antigen might be related to antibody inhibition of cadherin interactions (4) and may involve activation of the complement cascade (5) and/or plasminogen activators (6).

Address correspondence to Dr. Meenhard Herlyn, The Wistar Institute of Anatomy and Biology, 3601 Spruce Street, Philadelphia, PA 19104. Received for publication 19 February 1993 and in revised form 17 May 1993.

1. Abbreviations used in this paper: PV, pemphigus vulgaris; SCID, severe combined immunodeficiency disease.

J. Clin. Invest.

(C) The American Society for Clinical Investigation, Inc. $0021-9738 / 93 / 11 / 2401 / 07 \quad \$ 2.00$

Volume 92, November 1993, 2401-2407
Current experimental animal models for studies on the pathogenesis of PV are based on the passive transfer of patients' Ig to newborn mice (7) or of patients' sera to athymic nude mice engrafted with human oral mucosa (8). In the mucosal graft model, the incidence of epithelial cell detachment is low ( 3 of 25 grafts). Newborn mice injected with IgG fractions from pemphigus patients develop cutaneous blisters within 1 to $3 \mathrm{~d}$. The lesions disappear after discontinuation of IgG injections and repeated injections of adult mice with patients' Ig are without a pathogenic effect.

The availability of severe combined immunodeficiency (SCID) mice, which lack both functional B and T lymphocytes $(9,10)$, makes continuous production of human Ig in the murine host possible. In SCID mice grafted with human fetal liver and thymus cells (11) or PBL (12), the human cells home to lymphatic organs, thus reconstituting elements of the human immune system. Production of human Ig is seen after 2 to $4 \mathrm{wk}$ and remains detectable over 20 wk after engraftment. Lymphocytes from patients with autoimmune diseases such as systemic lupus erythematosus and biliary cirrhosis can be expanded in the murine host to reproduce the human disease $(13,14)$.

Lymphocytes from patients with pemphigus produce autoantibodies against epidermal and mucosal antigens (15). Because the human antibodies also bind to antigens on mouse keratinocytes $(1,16)$, we investigated the effect of continuous antibody exposure on keratinocytes on the development of PVlike disease in adult mice. Although SCID mice reconstituted with PBL from patients with PV rarely developed blisters in skin or mucous membranes, reconstituted mice that were previously grafted with full-thickness human skin developed PVlike blisters in the human grafts. Thus, SCID mice can provide an in vivo model for human pemphigus.

\section{Methods}

Reconstitution of SCID mice with human PBL. C.B.-17 SCID (scid/ scid) mice were bred at The Wistar Institute Animal Facility. At 6 wk of age, mice were tested for endogenous Ig production and only fully immunodeficient mice were used for experiments. PBL were obtained with informed consent from patients with PV or healthy adult volunteers by centrifugation of heparinized blood on Ficoll-Hypaque gradients (Pharmacia LKB, Piscataway, NJ). PBL in RPMI 1640 medium were administered intraperitoneally either immediately after separation or after 2-36-wk storage in liquid nitrogen. The viability of injected cells was $>90 \%$. The number of PBL injected varied initially between 1 and $10 \times 10^{7} /$ mouse; it was subsequently adjusted to $2.5-$ $3.0 \times 10^{7} /$ mouse. SCID mice within one group received equal numbers of lymphocytes from the same donor. Mice reconstituted with PBL from healthy volunteers and mice injected intravenously with 30 mg of human gammaglobulins prepared from healthy individuals (ICN Biomedicals Inc., Lisle, IL) served as controls. All animals were housed under pathogen-free conditions in microisolator cages and observed daily or at a minimum three times per wk.

Detection of human Ig. Total human IgG in plasma of reconsti- 


\begin{tabular}{|c|c|c|c|c|c|c|c|c|c|}
\hline \multirow[b]{2}{*}{ Donors } & \multirow[b]{2}{*}{$\begin{array}{l}\text { No. of } \\
\text { donors }\end{array}$} & \multirow[b]{2}{*}{$\begin{array}{l}\text { No. of mice } \\
\text { reconstituted }\end{array}$} & \multirow[b]{2}{*}{$\begin{array}{c}\text { PBL } \\
\left(\times 10^{7}\right)\end{array}$} & \multirow[b]{2}{*}{$\begin{array}{l}\text { No. of mice } \\
\text { evaluated }\end{array}$} & \multirow[b]{2}{*}{ Human IgG } & \multicolumn{3}{|c|}{ No. of mice/total tested } & \multirow{2}{*}{$\begin{array}{l}\text { No. of mice } \\
\text { with pemphigus } \\
\text { antibodies/No. } \\
\text { of mice without } \\
\text { lymphoma and } \\
\text { with } \operatorname{IgG} \geq 0.1\end{array}$} \\
\hline & & & & & & $\begin{array}{l}\text { Human } \\
\text { IgG } \geq 0.1\end{array}$ & $\begin{array}{c}\text { Circulating } \\
\text { human } \\
\text { anti-pemphigus } \\
\qquad \operatorname{IgG}^{\ddagger}\end{array}$ & $\begin{array}{c}\text { Epidermal } \\
\text { deposits } \\
\text { of human } \\
\operatorname{IgG}^{\$}\end{array}$ & \\
\hline & & & & & $m g / m l^{*}$ & $m g / m l$ & & & $m g / m l$ \\
\hline \multirow[t]{2}{*}{ PV } & 7 & 37 & $\leq 2.5$ & 37 & $7.94 \pm 21.8$ & $25 / 37$ & $16 / 36$ & $17 / 36$ & $16 / 18$ \\
\hline & 5 & 21 & $\geq 5$ & $12^{\| \prime}$ & $16.6 \pm 15$ & $9 / 12$ & $4 / 12$ & $4 / 12$ & $3 / 4$ \\
\hline Healthy adult & 4 & 20 & 2.5 & 18 & $2.36 \pm 2.49$ & $17 / 18$ & $0 / 17$ & $0 / 17$ & $0 / 11$ \\
\hline Normal human IgG' & $N / A^{* *}$ & 3 & N/A & 3 & $23.83 \pm 3.7$ & $3 / 3$ & $0 / 3$ & $0 / 3$ & $0 / 3$ \\
\hline
\end{tabular}

* Mean \pm SD calculated from maximal level in each mouse 4-8 wk after reconstitution. ${ }^{\ddagger}$ As determined in indirect immunofluorescence assays on sections of monkey esophagus. ${ }^{8}$ Spontaneous or after traumatization with heat $\left(60^{\circ} \mathrm{C}\right)$ or cold (liquid $\left.\mathrm{N}_{2}\right)$ as determined by direct immunofluorescence. "SCID mice not evaluated had died of lymphomas, unknown causes, or due to accidents. ' $20 \mathrm{mg} / \mathrm{mouse}$ i.v. ${ }^{* *} \mathrm{~N} / \mathrm{A}$, not applicable.

tuted SCID mice was measured by enzyme-linked immunosorbent assays in 96-well microtiter plates (Falcon Pro-bind; Becton Dickinson \& Co., Lincoln Park, NJ) coated with $5 \mu \mathrm{g} / \mathrm{ml}$ of goat IgG anti-human IgG (Sigma Chemical Co., St. Louis, MO). After overnight blockade with $1 \%$ BSA and subsequent washings, serial dilutions of mouse plasma were added, followed by peroxidase-conjugated goat IgG antihuman IgG ( $\gamma$-chain-specific; Sigma Chemical Co.). Antibody binding was visualized with the ABTS peroxidase substrate system (Kirkegaard-Perry, Gaithersburg, MD) and quantitated by comparison with a purified human IgG control preparation (Cappel Laboratories/Organon Teknika, Durham, NC).

Circulating PV antibodies in the plasma of reconstituted SCID mice were detected by indirect immunofluorescence assays on frozen sections of esophagus from African Green monkeys. For comparison of various substrates, air-dired sections of monkey esophagus, human skin, and murine skin were incubated with serial dilutions ( $1: 10$ to 1:320) of plasma from PV patients for $30 \mathrm{~min}$, washed in PBS, $\mathrm{pH} 7.3$, for $10 \mathrm{~min}$, and further incubated for $30 \mathrm{~min}$ with FITC-labeled goat IgG anti-human IgG. Slides were then covered with Fluoromount-G mounting medium (Fisher Scientific, Philadelphia, PA) and sealed. Sections were evaluated in a Leitz fluorescence microscope equipped with epi-illumination (Leitz USA, Deerfield, IL). PV antibodies in the epidermis stain in a typical cobblestone cell membrane pattern specific for this disease, allowing the routine clinical use of this assay for diagnosis.

For detection of human IgG in skin and mucous membranes by direct immunofluorescence, tissues were snap-frozen in OCT compound. Sections $(5 \mu \mathrm{m})$ were air-dried for $1 \mathrm{~h}$, fixed in $95 \%$ ethanol, and incubated for $30 \mathrm{~min}$ with FITC-conjugated goat IgG anti-human IgG. Slides were then washed and mounted. Portions of tissues (liver, lungs, spleen, pancreas, kidney, and lymph nodes) were fixed in $10 \%$ buffered formaldehyde for histopathological examinations. Sections (4 $\mu \mathrm{m})$ were stained with hematoxylin and eosin and analyzed under an Ortholux universal microscope (Leitz USA).

To facilitate human Ig deposition, dorsolateral skin of anesthetized mice was traumatized $8 \mathrm{wk}$ after reconstitution with PBL. A metal spatula immersed into liquid $\mathrm{N}_{2}$ was applied onto different sectors of the skin for 2,5 , and $15 \mathrm{~s}$, respectively, in a $5-\mathrm{cm}^{2}$ area previously treated with Zip Wax depilatory (Lee Pharma, El Monte, CA). A spatula, heated in water to $60^{\circ} \mathrm{C}$, was then applied in three different sectors of the skin for 15,30 , and $60 \mathrm{~s}$, respectively. Mice were sacrificed $24 \mathrm{~h}$ later and biopsies were obtained for histological and immunofluorescence assays.

Immunoprecipitation of PV antigen by antibodies in human and mouse plasma was done as described (1) using the squamous cell carcinoma cell line SCaBER (17) and normal human keratinocytes as antigen source. Briefly, confluent monolayer cells were detached with 100
mM Versene (GIBCO BRL, Gaithersburg, MD), washed with PBS, and labeled for $1 \mathrm{~h}$ with $0.1 \mathrm{mg} / \mathrm{ml}$ NHS-LC-Biotin (Pierce Chemicals, Rockford, IL), followed by lysis with RIPA buffer ( $1 \%$ sodium deoxycholate, $1 \%$ Triton X-100, and $0.1 \%$ SDS ) containing $0.05 \mathrm{mM}$ PMSF (Sigma Chemical Co.). The solubilized material was centrifuged at $36,000 \mathrm{~g}$ for $10 \mathrm{~min}$ at $4^{\circ} \mathrm{C}$ and the supernatant was dialyzed against $0.3 \%$ NP-40. Aliquots of plasma samples of reconstituted SCID mice and control plasma or sera of patients with PV were incubated with 100 $\mu$ l protein $\mathrm{G}$ Sepharose for $1 \mathrm{~h}$ at $4^{\circ} \mathrm{C}$ and washed three times with RIPA buffer. Overnight incubation of the cell lysate with the Sepharose-antibody complexes was followed by vigorous washing in RIPA buffer. The prepared material was then run on a $10 \%$ polyacrylamide gel containing $1 \%$ SDS (18). Bands were visualized by avidin-conjugated alkaline phosphatase and 5-bromo, 4-chloro, 3-indolylphosphate/nitroblue tetrazolium (Sigma Chemical Co.) as substrate.

Transplantation of human skin to SCID mice. Six- to 8-wk-old SCID mice received transplants of full-thickness human skin. A circular graft bed $\sim 1.5 \mathrm{~cm}$ in diameter was prepared in the depilated lateral abdominal region. Mouse skin down to the fascia was then removed with curved scissors and human skin from either neonatal foreskin or adult human breast (discarded skin from reduction mammoplasty) were placed onto the wound bed and held in place with 5-0 monofilament sutures (Dermalon; Davis \& Geck Inc., Danbury, CT). The transplantation site was then covered with a Band-Aid ${ }^{\mathrm{TM}}$ and clipped

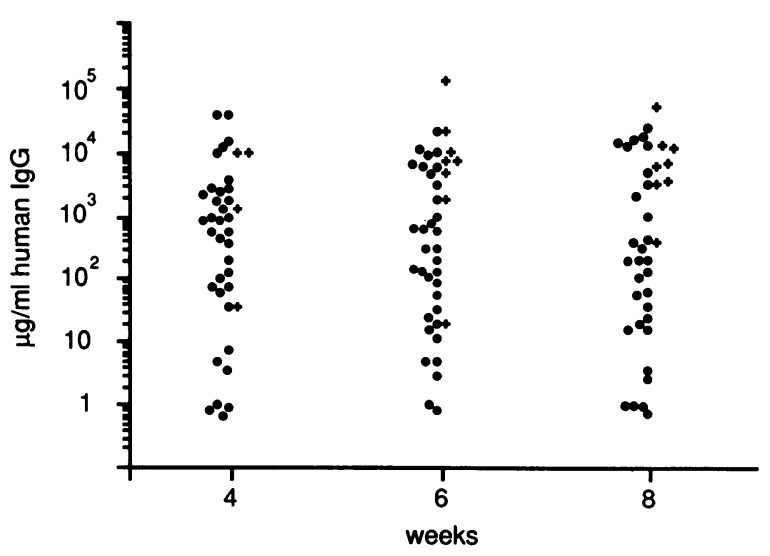

Figure 1. Production of human Ig in SCID mice reconstituted with PBL from patients with PV. Plasma levels of human IgG 4, 6, and 8 wk after reconstitution are given for individual mice without $(\bullet)$ or with $(+)$ evidence of lymphoma upon necropsy. 
dorsally and ventrally to the mouse skin using surgical staples (Autoclip; Clay Adams, Parsippany, NJ). A layer of Micropore surgical tape (3M Co., St. Paul, MN) was then applied. Grafted mice were housed in individual cages. After $4 \mathrm{wk}$, grafts had healed and mice were reconstituted with PBL from patients with PV. If blisters appeared after reconstitution, mice were sacrificed and skin grafts with the surrounding murine skin were removed for histological examination. Parts of the grafts were snap-frozen in OCT, fixed in $10 \%$ buffered formaldehyde, and embedded in paraffin. Skin-grafted control mice that received PBL from healthy donors and that had not developed blisters were killed 5 wk after administration of PBL for histological examination of skin grafts.

\section{Results}

Presence of human Ig in reconstituted SCID mice. SCID mice reconstituted with PBL from 12 patients with PV and 4 healthy donors contained circulating human IgG. 4 to 8 wk after reconstitution with $1-10 \times 10^{7} \mathrm{PBL} /$ mouse, 34 out of 49 mice (69\%) had human IgG levels of at least $0.1 \mathrm{mg} / \mathrm{ml}$, with a mean of $12.27 \mathrm{mg} / \mathrm{ml}$ (Table I, Fig. 1). The mean IgG levels were higher if mice were reconstituted with $5-10 \times 10^{7} \mathrm{PBL} /$ mouse than with $1-2.5 \times 10^{7} \mathrm{PBL} /$ mouse $(16.6 \mathrm{mg} / \mathrm{ml} \mathrm{vs}$. $7.94 \mathrm{mg} / \mathrm{ml}$, respectively). Human IgG was detected as early as $3 \mathrm{wk}$ after reconstitution and, in individual mice tested, for at least 24 wk. Mice with $\mathrm{IgG}$ levels of $10 \mathrm{mg} / \mathrm{ml}$ or more often subsequently developed abdominal lymphomas (Fig. 1). 5 out of 37 mice $(13.5 \%)$ reconstituted with $1-2.5 \times 10^{7}$ PBL and 5 out of 12 mice $(41.6 \%)$ reconstituted with $5-10 \times 10^{7}$ PBL had clinically or histologically confirmed lymphomas. Focal hepatic infiltration (19) was seen in 5 out of 37 mice $(13.5 \%)$ injected with $1-2.5 \times 10^{7}$ and 8 out of $12(66 \%)$ mice injected with $5 \times 10^{7} \mathrm{PBL}$ (data not shown). Due to the higher inci-
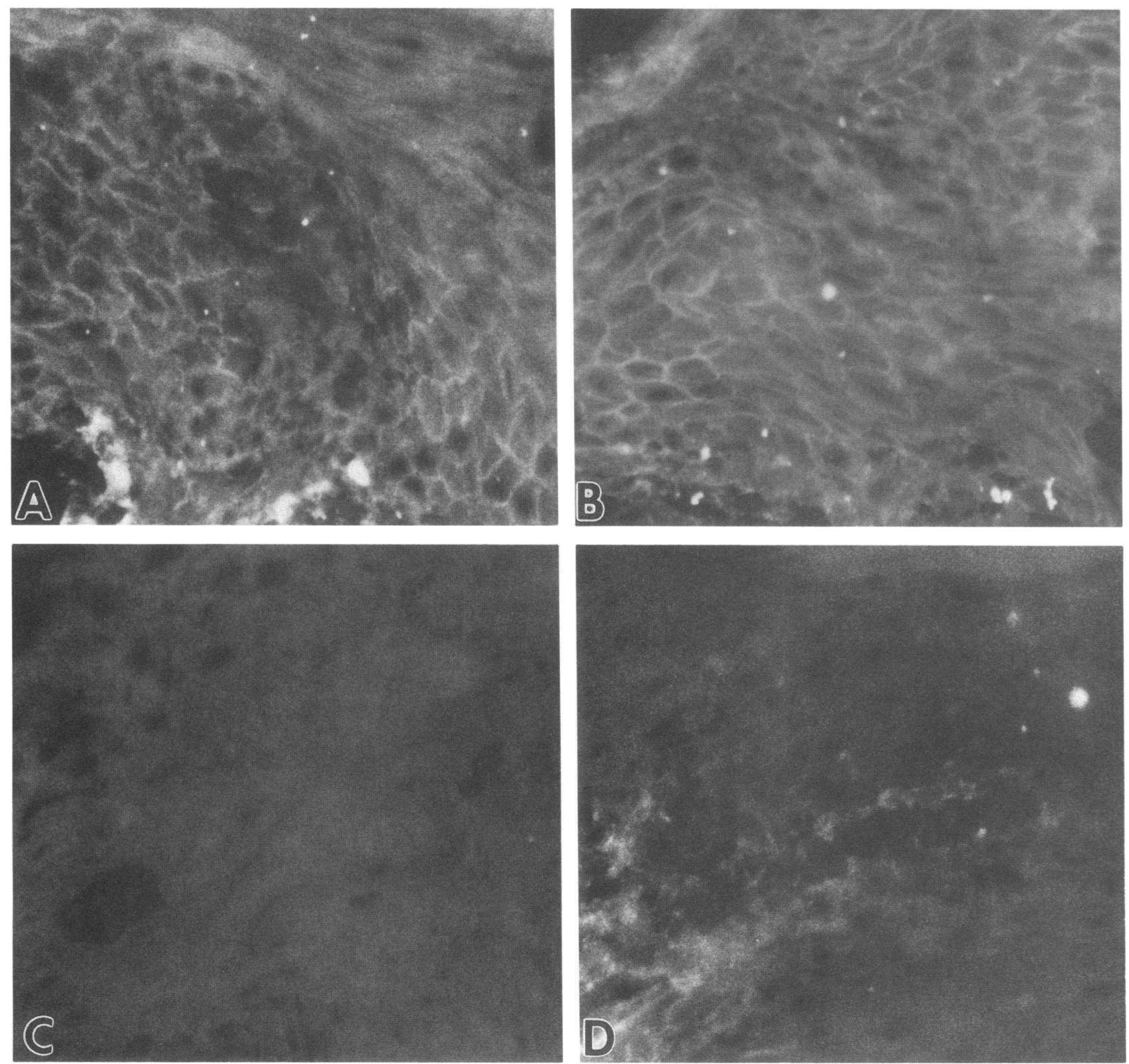

Figure 2. Indirect immunofluorescence assay for PV antibodies on sections of monkey esophagus. $(A)$ Plasma from a SCID mouse reconstituted with PBL from a patient with PV. (B) Plasma from the same patient as in $A$. (C) Plasma of a SCID mouse reconstituted with PBL from a healthy donor. (D) Normal human plasma. 


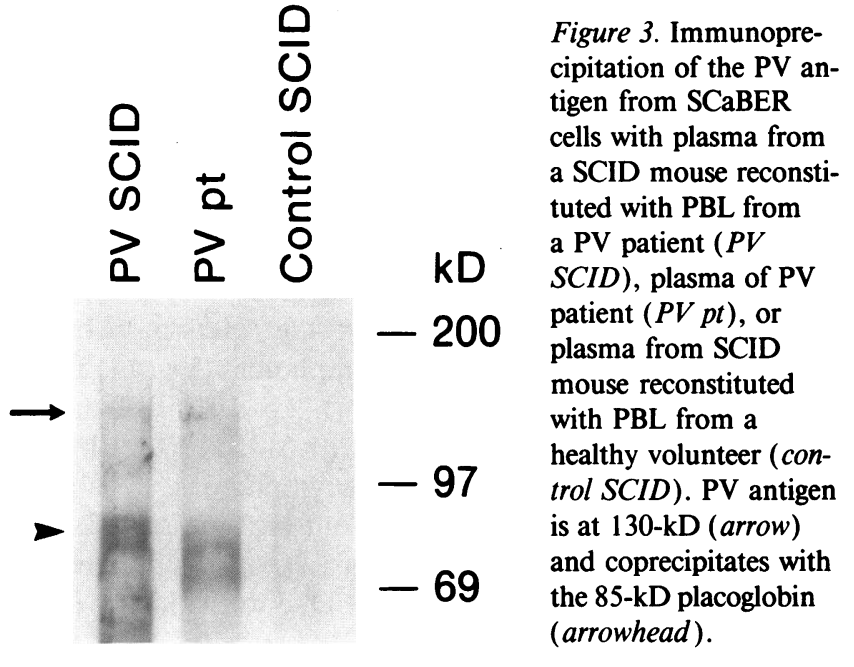

dence of lymphomas with time after reconstitution, mice were killed after 8 wk and the number of PBL was restricted to 2.5$3.0 \times 10^{7} /$ mouse.

Presence of anti-PV antibodies in SCID mice. 20 of the 34 mice $(58 \%)$ that produced human IgG also had circulating antibodies with a PV-like binding pattern on tissue sections of monkey esophagus. The staining pattern in plasma from SCID mice reconstituted with PV patients' PBL was similar to that of patients' plasma (Fig. $2 A$ and $B$ ) whereas plasma from healthy donors or from mice reconstituted with PBL from normal donors did not stain tissue (Fig. $2 C$ and $D$ ) nor did plasma of mice injected with normal human IgG (not shown). The presence of anti-PV antibodies in the plasma of reconstituted mice was confirmed in immunoprecipitation experiments with epithelial cells as antigen source (Fig. 3). Antibodies in plasma of reconstituted mice and plasma/sera of PV patients bound the 130-kD PV antigen and co-precipitated the $85-\mathrm{kD}$ placoglobin.

Spontaneous human IgG deposits in mouse skin associated with suprabasal acantholytic blister formation were occasionally observed (Fig. $4 A$ ). Of the reconstituted mice in which the skin was traumatized by heat or cold (see protocol), 21 (44\%) showed skin IgG deposits adjacent to the site of trauma (Fig. 4 $B$ ). By contrast, neither mice reconstituted with PBL from healthy donors (Fig. $4 C$ ) nor those injected with human IgG (not shown) showed specific deposits in skin after traumatization.

Blistering disease in reconstituted SCID mice grafted with human skin. Human skin is the natural substrate for human anti-pemphigus antibodies in contrast to skin from adult mice. To determine whether human anti-pemphigus antibodies induce blister formation more readily in human than in mouse skin, 1.5 to $2 \mathrm{~cm}^{2}$ full-thickness human skin grafts were applied to the lateral abdomen of SCID mice (Fig. $5 \mathrm{~A}$ ); and 4 wk later, 16 mice were reconstituted with $2.5-3 \times 10^{7}$ PBL from patients with PV or from normal donors (Table II). 16 to $33 \mathrm{~d}$ later, mice reconstituted with patients' PBL developed lesions in the grafted human skin that varied from 3-mm erosions to denudation and crusting of the grafts (Fig. 5 B). Histologically, the skin adjacent to erosions showed intraepidermal cell dyshesion, with rounded acantholytic cells (Fig. $5 C$ ). PV-like intercellular deposition of human IgG in the grafted human epidermis was found by direct immunofluorescence assays (Fig. $5 \mathrm{D}$ and $E$ ). PBL from normal donors did not induce blistering lesions after injection into grafted SCID mice, and no epidermal IgG deposits were observed (not shown).

\section{Discussion}

SCID mice reconstituted with PBL from pemphigus patients had circulating anti-pemphigus antibodies. These antibodies rarely induced spontaneous blisters in mouse skin but consistently bound to epidermal keratinocytes after the skin was mildly traumatized by heat or cold. SCID mice first grafted with full-thickness human skin, which were then reconstituted with pemphigus patients' PBL, consistently had human antibody deposits in the human grafts that were often associated with spontaneous blistering 18 to $33 \mathrm{~d}$ after reconstitution.

Although the staining pattern of human anti-pemphigus antibodies in mouse skin was similar to that in human skin, PV
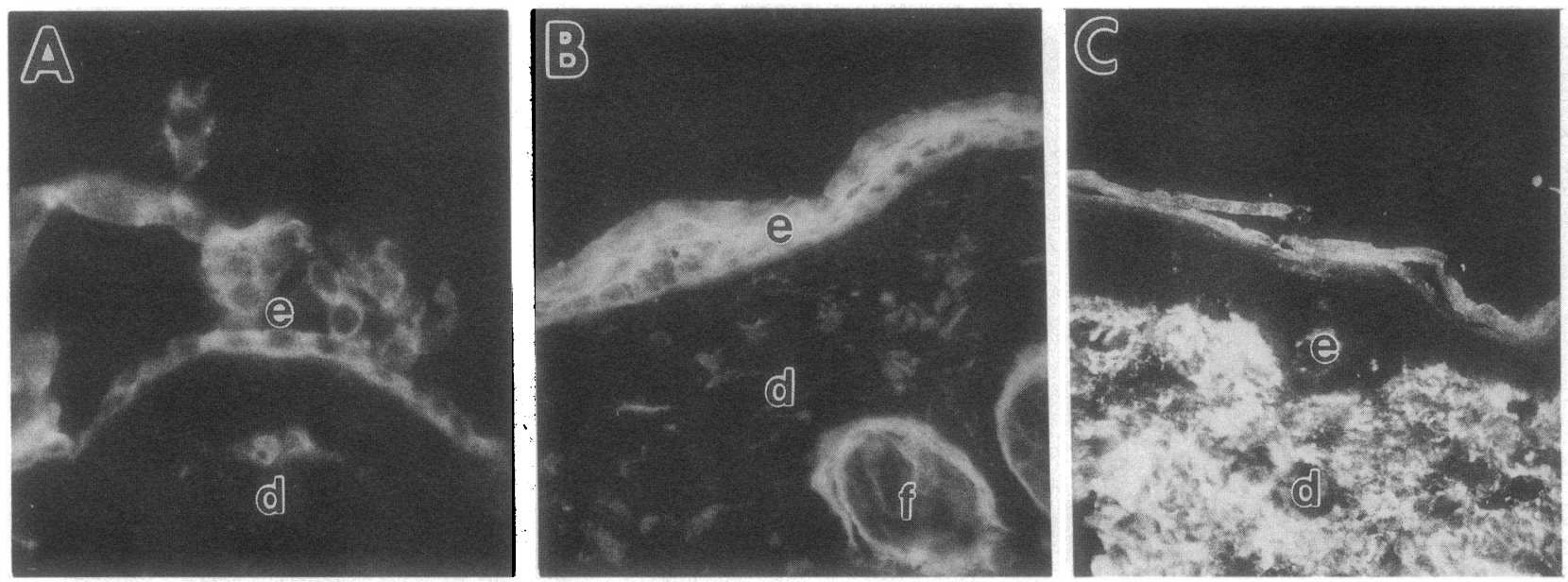

Figure 4. Direct immunofluorescence assay of skin from reconstituted SCID mice. Sections are stained with FITC-labeled goat IgG anti-human IgG. (A) Spontaneous blister in skin of a SCID mouse reconstituted with PBL from a patient with PV (e, epidermis; $d$, dermis). (B) Intercellular deposition of human IgG in the perilesional murine epidermis $24 \mathrm{~h}$ after traumatization of skin with $60^{\circ} \mathrm{C}$ heat for $30 \mathrm{~s}(f$, hair follicle $) .(C)$ Traumatized skin of a SCID mouse reconstituted with PBL from a healthy donor (note that the dermis has accumulation of human IgG, but intraepidermal deposition is absent). 

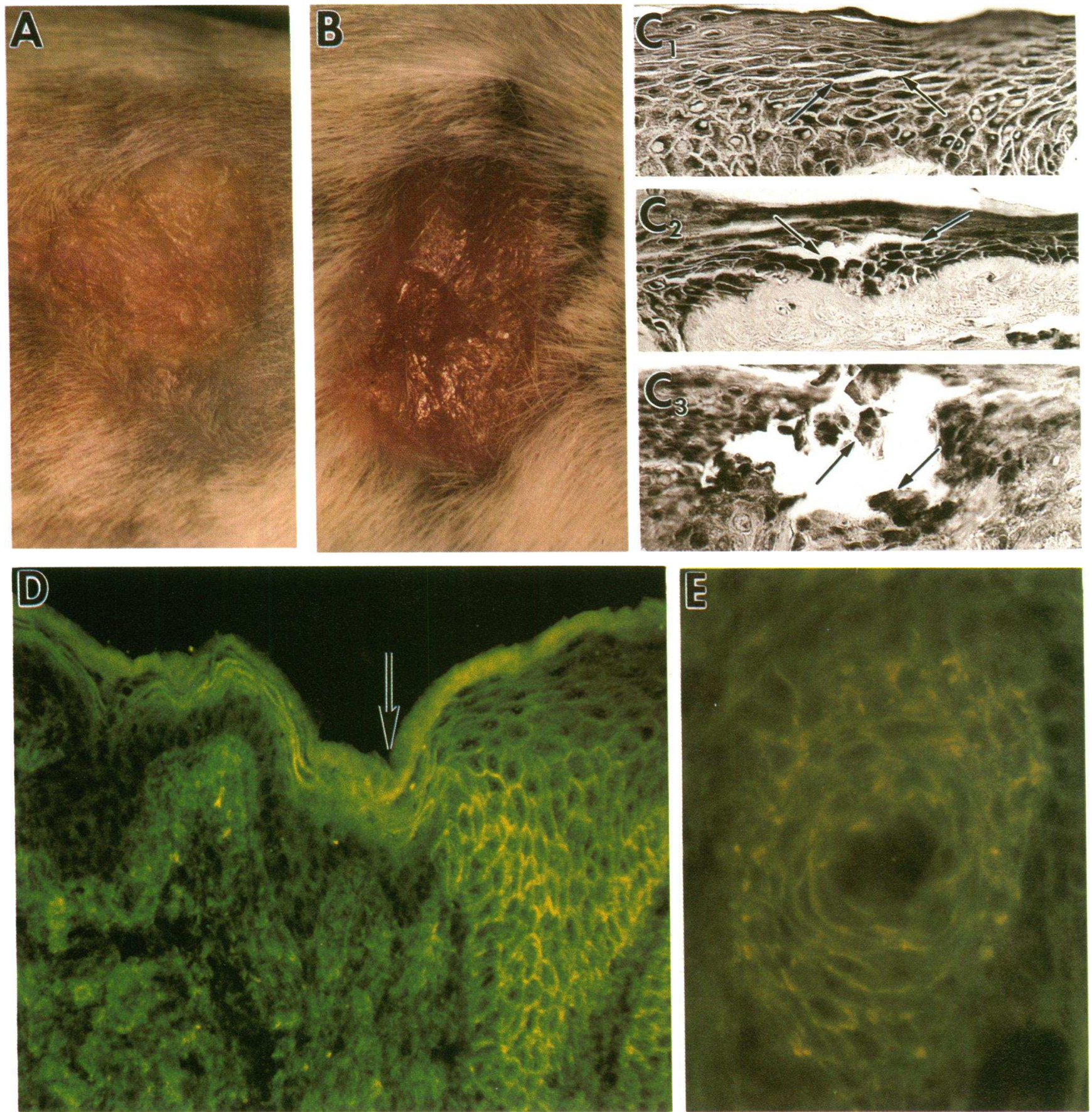

Figure 5. PV-like disease in human skin grafted to SCID mice. $(A)$ Full-thickness human skin transplant on a SCID mouse 10 wk after engraftment. $(B)$ Eroded blister formed spontaneously in grafted human skin on a SCID mouse $18 \mathrm{~d}$ after reconstitution with PBL from a patient with PV. (C) Spontaneous blister formed in grafted human skin. Routine histology of lesional xenografted skin revealed foci of cleft-like separation devoid of intercellular junctions between keratinocytes $\left(C_{1}\right.$, arrows $)$; forming suprabasal and mid-epidermal blisters bordered by rounded, acantholytic keratinocytes $\left(C_{2}\right.$, arrows); and containing degenerating acantholytic cells $\left(C_{3}\right.$, arrows $) \times 150$. (D) Pemphigus-like intercellular deposition of human IgG in grafted human epidermis. Immunostaining with FITC-labeled goat antibodies to anti-human IgG. Arrow shows acantholytic junction between grafted human skin (right) and recipient murine skin (left). (E) Perifollicular deposition of human IgG in the grafted human skin from the same section as $(D)$.

antigen appears expressed in greater amounts on human than on mouse skin. Possibly, human antibodies recognize epitopes on the PV antigen that are masked or absent on the murine antigen. The human PV antigen has recently been identified as a member of the cadherin family (3); the degree of sequence homology to the mouse equivalent has not yet been established. Differences in protein sequence, glycosylation, or cell surface exposure of the PV antigen may further account for differences in antibody binding between human and mouse skin. Reconstitution of adult mice with pemphigus patients' 
Table II. Induction of Blistering Lesions in Grafted Human Skin After Reconstitution of SCID Mice with PBL from Patients with PV

\begin{tabular}{|c|c|c|c|c|c|c|c|c|}
\hline Donors & & $\begin{array}{c}\text { Skin } \\
\text { transplant }\end{array}$ & $\begin{array}{l}\text { PBL } \\
\left(\times 10^{7}\right)\end{array}$ & $\begin{array}{c}\text { Maximum } \\
\text { human IgG }\end{array}$ & Lesion in human skin & $\begin{array}{l}\text { Days to } \\
\text { blister } \\
\text { formation }\end{array}$ & Histology & $\begin{array}{c}\text { Human IgG } \\
\text { deposits } \\
\text { in lesion }\end{array}$ \\
\hline & & & & $m g / m l$ & & & & \\
\hline \multirow[t]{12}{*}{ PV patient } & $A^{*}$ & newborn & 3 & 0.3 & oval erosion & 20 & blister & present \\
\hline & $\mathbf{A}$ & adult & 3 & 0.12 & $1.5 \times 3 \mathrm{~mm}$ erosion & 19 & acantholysis & absent \\
\hline & B & adult & 3 & 0.08 & crust & 28 & $\begin{array}{l}\text { blister wall, } \\
\text { acantholysis }\end{array}$ & present \\
\hline & B & newborn & 3 & 0.015 & non & - & $\begin{array}{l}\text { no signs of blister } \\
\text { formation }\end{array}$ & absent \\
\hline & $\mathrm{C}$ & newborn & 3 & $\mathrm{NT}^{\S}$ & hemorrhage & 18 & blister & present \\
\hline & $\mathrm{C}$ & adult & 3 & 2.42 & blister & & blister & present \\
\hline & $\mathrm{C}$ & adult & 2.5 & 1.8 & 5-mm eroded blister & 33 & blister not detected & present \\
\hline & $\mathrm{C}$ & adult & 2.5 & 0.002 & necrosis & 16 & $\begin{array}{l}\text { part of epidermis } \\
\text { covered with crust }\end{array}$ & absent \\
\hline & $\mathrm{C}$ & newborn & 2.5 & 0.41 & 3-mm crust & 14 & blister & present \\
\hline & $\mathrm{C}$ & newborn & 3 & 1.49 & 1-mm erosion & - & $\|$ & present \\
\hline & $\mathrm{C}$ & newborn & 3 & 0.28 & 2-mm erosion & - & blister not detected & present \\
\hline & $\mathrm{C}$ & adult & 3 & 15.2 & dead by day 23 & - & blister not detected & $\mathrm{NT}^{\beta}$ \\
\hline \multirow[t]{4}{*}{ Healthy donor } & $\mathrm{D}$ & newborn & 3.0 & 0.53 & none & - & $\begin{array}{l}\text { no signs of blister } \\
\text { formation }\end{array}$ & absent \\
\hline & $\mathrm{D}$ & newborn & 3.0 & 1.3 & none & - & $\begin{array}{l}\text { no signs of blister } \\
\text { formation }\end{array}$ & absent \\
\hline & D & newborn & 3.0 & 0.02 & none & - & $\begin{array}{l}\text { no signs of blister } \\
\text { formation }\end{array}$ & absent \\
\hline & $E$ & newborn & 3.0 & 0.82 & none & - & $\begin{array}{l}\text { no signs of blister } \\
\text { formation }^{\ddagger}\end{array}$ & absent \\
\hline
\end{tabular}

* Same letters indicate same donor. ${ }^{\ddagger} 35 \mathrm{~d}$ after reconstitution. ${ }^{8}$ Not tested. "Graft difficult to evaluate. ' Tissue area with erosion lost during tissue block preparation.

PBL rarely induced blisters in the mouse skin; passive administration of isolated IgG from pemphigus patients, results in blister formation in mouse skin only if newborn animals are injected with large $\mathrm{Ig}$ quantities of up to $1 \mathrm{~g}(7)$. On the other hand, adult mice first grafted with human skin and then reconstituted with patients' PBL spontaneously developed blisters in the grafts with a histological pattern that is the same as in the naturally occurring disease in patients. The human skin grafts retained their architecture, including a dermal vasculature, for several months after grafting, allowing penetration of antibodies through the basement membrane to the epidermis in the same way as in human skin. Human blood vessels anastomose with the murine vasculature at the graft bed and, upon stimulation by human tumor cells, human vessels in the skin grafts sprout into the expanding tumor mass (19).

SCID mice reconstituted with human PBL showed little evidence of graft-vs.-host disease and studies by others indicate varied reactions, ranging from lymphocytic infiltration around hepatic bile ducts $(12,13)$ to focal liver necrosis $(20)$. We observed only focal infiltrates of CD45-positive cells in livers in 13 of 49 mice (data not shown). The observed variation of human IgG levels in reconstituted mice is consistent with previous studies $(13,21,22)$. Mice with high IgG levels (> 15 $\mathrm{mg} / \mathrm{ml}$ ) often developed lymphomas, which are commonly found in SCID mice reconstituted with PBL from EBV-positive donors (23). The time course of EBV-induced lymphomas varies depending on the percentage of EBV-positive cells in the total lymphocyte population and the total injected dose (12). To delay lymphoma development, we restricted the number of injected PBL to $2-3 \times 10^{7}$ per mouse and completed the experiments 8 wk after reconstitution.

The routine screening of mice for "leakiness," i.e., spontaneous IgM production, at 6 to $8 \mathrm{wk}$ of age and the use of mice under the age of $12 \mathrm{wk}$ helped prevent failures in reconstitution (24). Transplantation of human skin (25) in our laboratory was successful in $90 \%$ of more than 200 transplantations if the grafted human foreskin was used no later than $2 \mathrm{~d}$ after resection and if the adult skin showed no evidence of trauma from handling during surgery. We detected no obvious graft-vs.-graft reactions despite the use of allogeneic skin in these experiments in reconstituted mice. It remains to be determined whether any inflammatory reactions due to possible histoincompatibility of human PBL and skin contributes to blister development in this model. Autologous skin grafts from pemphigus patients were not done due to ethical considerations.

Models in experimental animals that closely mimic human antibody-mediated autoimmune diseases are rare. The animal model described here closely represents the naturally occurring disease because it involves both antibody-producing lymphocyte effector cells and epidermal keratinocytes (target cells) of human origin. Studies using this model can begin to address the questions that remain concerning the effector mechanisms of PV blister formation, the clonality of the antibody response in PV patients, and the identification of immunodominant epi- 
topes on the PV antigen. The recent cloning of the PV antigen (3) should aid in epitope mapping efforts. The SCID model for PV should also be useful in developing new therapeutic approaches that go beyond the current symptomatic treatment with corticosteroids.

\section{Acknowledgments}

We thank Ms. T. Egner for help in animal experiments, Ms. E. Aglow and Ms. A. Radu for their assistance in histological studies, and Dr. J. Stanley for providing us with serum from a patient with PV for control to our immunoprecipitation experiments.

This work was supported in part by grants from the National Institutes of Health, CA-25874, CA-10815, and AR-39674.

\section{References}

1. Stanley, J. R., M. Yaar, P. Hawley-Nelson, and S. I. Katz. 1982. Pemphigus antibodies identify a cell surface glycoprotein synthesized by human and mouse keratinocytes. J. Clin. Invest. 70:281-288.

2. Cowin, P., H. P. Kapprell, W. W. Franke, J. Tamkun, and R. O. Hynes. 1986. Plakoglobin: a protein common to different kinds of intercellular adhering junctions. Cell. 46:1063-1073.

3. Amagai, M., V. Klaus-Kovtun, and J. R. Stanley. 1991. Autoantibodies against a novel epithelial cadherin in pemphigus vulgaris, a disease of cell adhesion. Cell. 67:869-877.

4. Amagai, M., S. Karpati, R. Prussick, V. Klaus-Kovtun, and J. R. Stanley 1992. Autoantibodies against the cadherin-like homophilic binding region of pemphigus vulgaris antigen cause acantholysis. J. Invest. Dermatol. 98:566. (Abstr.)

5. Kawana, S., W. D. Geoghegan, R. E. Jordon, and S. Nishiyama. 1989. Deposition of the membrane attack complex of complement in pemphigus vulgaris and pemphigus foliaceous skin. J. Invest. Dermatol. 92:588-592.

6. Farb, R. M., R. Dykes, and G. S. Lazarus. 1978. Anti-epidermal-cell-surface pemphigus antibody detaches viable epidermal cells from culture plates by activation of proteinase. Proc. Natl. Acad. Sci. USA. 75:459-463.

7. Anhalt, G. J., R. S. Labib, J. J. Voorhees, T. F. Beals, and L. A. Diaz. 1982 Induction of pemphigus in neonatal mice by passive transfer of IgG from patient with the disease. N. Engl. J. Med. 306:1189-1196.

8. Buschard, K., E. Dabelsteen, and P. Bretlau. 1981. A model for the study of autoimmune diseases applied to pemphigus: transplants of human oral mucosa to athymic nude mice binds pemphigus antibodies in vivo. J. Invest. Dermatol. 76:171-173.

9. Bosma, G. C., R. P. Custer, and M. J. Bosma. 1983. A severe combined immunodeficiency mutation in the mouse. Nature (Lond.). 301:527-530.

10. Schuler, W., I. J. Weiler, A. Schuler, R. A. Phillips, N. Rosenberg, T. W. Mak, J. F. Kearney, R. P. Perry, and M. J. Bosma. 1986. Rearrangement of antigen receptor genes is defective in mice with severe combined immune deficiency. Cell. 46:963-972.

11. McCune, J. M., R. Namikawa, H. Kaneshima, L. D. Shultz, M. Lieberman, and I. L. Weissman. 1988. The SCID-hu mouse: murine model for the analysis of human hematolymphoid differentiation and function. Science ( Wash. DC). 241:1632-1639.

12. Mosier, D. E., R. J. Gulizia, S. M. Baird, and D. B. Wilson. 1988. Transfer of a functional human immune system to mice with severe combined immunodeficiency. Nature (Lond.). 335:256-259.

13. Krams, S. M., K. Dorshkind, and M. E. Gershwin. 1989. Generation of biliary lesions after transfer of human lymphocytes into severe combined immunodeficient (SCID) mice. J. Exp. Med. 170:1919-1930.

14. Duchosal, M. A., P. J. McConahey, C. A. Robinson, and F. J. Dixon. 1990. Transfer of systemic lupus erythematosus in severe combined immunodeficient (SCID) mice. J. Exp. Med. 172:985-988.

15. Fitzmaurice, M., and S. D. Deodhar. 1984. Pemphigus and pemphigoid antibody production by pokeweek mitogen-stimulated peripheral blood mononuclear cell cultures in vitro. Am. J. Clin. Pathol. 81:586-590.

16. Labib, R. S., B. Rock, C. R. Martins, and L. A. Diaz. 1990. Pemphigus foliaceus antigen: characterization of an immunoreactive tryptic fragment from BALB/c mouse epidermis recognized by all patients' sera and major autoantibody subclasses. Clin. Immunol. Immunopathol. 57:317-329.

17. Mirza, N. M., A. Mohimen, and A. R. Ahmed. 1990. Detection of pemphigus vulgaris antigen on Colo and SCaBER tumor cell lines by the immunoblot technique. Arch. Dermatol. Res. 282:418-420.

18. Laemmli, U. K. 1970. Cleavage of structural proteins during assembly of the head of bacteriophage T4. Nature (Lond.). 277:680-685.

19. Juhasz, I., S. M. Albelda, D. E. Elder, G. F. Murphy, K. Adachi, D. Herlyn, I. T. Valyi-Nagy, and M. Herlyn. 1993. Growth and invasion of human melanomas in human skin grafted to immunodeficient mice. Am. J. Pathol. 143:413-428.

20. Pirruccello, J., H. Nakamine, K. W. Beisel, K. L. Kleveland, M. Okano, Y. Taguchi, J. R. Davis, M. L. Mahloch, and D. T. Purtilo. 1992. Hemagglutination and graft-versus-host disease in the severe combined immunodeficiency mouse lymphoproliferative disease model. Am. J. Pathol. 140:1187-1194.

21. Simpson, E., J. Farrant, and P. Chandler. 1991. Phenotypic and functional studies of human peripheral blood lymphocytes engrafted in scid mice. Immunol. Rev. 124:97-111.

22. Smith, C. I. E., M. R. Abedi, K. B. Islam, M. E. B. Johansson, B. Christensson, and L. Hammarström. 1991. Humoral immunity in SCID mice reconstituted with cells from immunoglobulin-deficient or normal humans. Immunol. Rev. 124:113-138.

23. Cannon, M. J., P. Pisa, R. I. Fox, and N. R. Cooper. 1990. Epstein-Barr virus induces aggressive lymphoproliferative disorders of human $B$ cell origin in SCID/hu chimeric mice. J. Clin. Invest. 85:1333-1337.

24. Bosma, G. C., M. Fried, R. P. Custer, A. M. Carrol, D. M. Gibson, and M. J. Bosma. 1988. Evidence of functional lymphocytes in some (leaky) SCID mice. J. Exp. Med. 167:1016-1033.

25. Kim, Y. H., D. T. Woodley, K. C. Wynn, W. Giomi, and E. A. Bauer. 1991. Recessive dystrophic epidermolysis bullosa phenotype is preserved in xenografts using SCID mice: development of an experimental in vivo model. J. Invest. Dermatol. 98:191-197. 